\title{
PENBINAAN KEBUGARAN JASMANI PADA USIA LANJUT
}

Oleh: Paiman

Guru Penjasorkes SMPN 5 Wates

\section{ABSTRAK}

Penuaan merupakan kejadian yang pasti dialami oleh setiap manusia. Dalam tubuh terjadi proses perubahan sruktur sel yang merupakan proses degeneneratif. Misalnya pembelahan sel melambat, sel mengecil, perubahan kompomsisi dan isi sel, serta timbulnya kemunduran fungsifungsi organ tubuh.

Proses penuaan ini dapat diperlambat dengan tetap bekerja, makan makanan yang bergizi, berolah raga yang teratur dan terukur, perawatan tubuh yang baik, suana hati yang senang dan damai, serta aktif kegiatan sosial. Orang beriman dengan aktif beribadah banyak dikir, wirid, sholat sunah, membaca kitap suci dan amalan amalan lainnya, dari pengamatan diketahui bahwa orang yang aktif beribadah di usia lanjut lebih lambat pikun dibanding lansia yang tidak aktif beribadah. Hal ini mungkin disebabkan lansia yang aktif beribadah ini masih tetap mengaktifkan otak dengan cara selalu menginggat waktu datangnya sholat, menghafal doa-doa, membaca kitap suci, melakukan amalan-amalan sunah dan sebagainya.

Usaha mempertahankan kebugaran lansia dapat ditempuh dengan cara-cara sebagai berikut: tetap aktif latihan fisik/olahraga, berpola hidup sederhana, hindari gaya hidup selalu terburu- 
buru, menjaga kerja Jantung tetap landai, menolong perut dari menderita borok perut, sering menghirup udara yang bersih, berjemur di sinar Matahari pagi, mengendurkan syaraf, menghindari keluh-kesah, menghindari stress, makan makanan yang sehat dan alami, hindari ketergantungan pada obat, tetaplah aktif membaca dan menulis, melakukan rekreasi yang ringan dan murah, dan semakin giat menjalankan ibadah.

Kata Kunci: Kebugaran, Lansia, Usaha mempertahankan.

Perbaikan gizi, pelayanan kesehatan, kesadaran akan pentingnya kebersihan akan meningkatkan kualitas lanjut usia. Para lansia mampu mendorong dirinya melakukan adaptasi terhadap perubahan yang terjadi pada dirinya dengan semangat optimisme, kebijaksanaan, kearifan dan bebas dari tekanan ambisi kehidupan serta berada dalam kondisi sehat jasmani dan rohani. Jika para lansia tidak dapat menyesuaian dengan perubahan yang terjadi saat usia senja maka akan mengalami kesengsaraan, kesedihan, serta penderitaan lahir batin. Semangat yang tinggi tidak lagi didukung oleh tenaga yang mencukupi, kondisi fisik yang semakin menurun, menurunnya kedudukan sosial dan jabatan, dan sebagainya memicu menurunnya kualitas kebugaran jasmani lansia. Namun masih banyak lansia yang memasuki usia lanjut masih tetap semangat, enerjik, penuh

MEDIKORA Vol. IV, No 2, Oktober 2008: 146-167 
percaya diri, dan masih aktif dalam kegiatan kemasyarakatan.

Organisasi lansia Yang berkembang dan dilaksanakan hampir di setiap desa dengan kegiatan olahraga jantung sehat yang dilakukan secara teratur, terukur dan terawasi serta berkelanjutan akan dapat mempertahankan tingkat kebugaran para lansia. tingkat kebugaran yang tinggi bagi lansia akan menjadikan tetap produktif di usia senja dan dapat memperpanjang usia harapan hidup. Pada kondisi yang semakin melemah lansia tidak lagi menjadi beban keluarga tetapi tetap produktif, aktif, bermanfaat, dan semakin rajin beribadah.

Kemanjuan ilmu pengetahuan dan teknologi khususnya ilmu kedokteran diperkirakan menjadikan usia harapan hidup di Indonesia semakin panjang. Diperkirakan pada tahun 2005-2010 jumlah penduduk usia lanjut mencapai 20 juta jiwa. Hal ini berpengaruh pada tingkat perekonomian bangsa.

Undang-undang No 23 tahun 1992 tentang kesehatan, pasal 19 menetapkan bahwa kesehatan manusia lansia tetap terpelihara dan ditingkatkan agar tetap produktif. Untuk itu yayasan jantung sehat Indonesia memberikan kepada para lansia untuk mendirikan klub-klub jantung sehat lansia 
untuk aktif berolahraga sebagai upaya dalam memelihara kesehatan jasmani, untuk mencegah gangguan kesehatan secara dini, dan kerusakan fisik serta masalah lain yang menyertainya.

Kebugaran jasmani pada usia senja sangat penting manfaatnya agar para lansia ini tetap dalam keadaan mandiri, produktif, aktif, bahagia, dan menjalani usia senja dengan sedikit tergantungan dengan orang lain/keluarga.

Keadaan pentingnya kebugaran ini belum disadari sepenuhnya oleh para lansia terutama bagi para lansia yang berpendidikan dan status ekonomi rendah. Ada rasa keengganan bagi para lansia ini karena beranggapan bahwa olahraga misalnya jalan pagi, senam jantung sehat, sepeda santai, dan kegiatan sosial lainnya merupakan aktifitas yang pantas dilakukan oleh para lansia yang berstatus sosial tinggi/berpendidikan tinggi. Kalangan lansia termajinal ini beranggapan bahwa olahraga merupakan kegiatan yang tidak produktif/membuang waktu sia-sia. Kadang-kadang para lansia termajinal ini kurang percaya diri jika harus berkumpul dengan para lansia yang mendapat kedudukan status sosial yang tinggi misalnya para pensiunan, orang kaya, dan berpendidikan tinggi sehingga cenderung menjauh dari aktifitas yang diprogramkan oleh organisasi lansia yang

MEDI KORA Vol. IV, No 2, Oktober 2008: 146-167 
telah ada sampai tingkat pedesaan/kelurahan. Fenomena menunjukkan bahwa dewasa ini semakin banyak para lansia dalam keadaan kesendirian padahal mempunyai anak. Anakanak setelah dewasa bekerja di luar daerah memaksa harus meninggalkan orang tuanya yang keadaan fisik semakin melemah dan butuh bantuan.

Indonesia adalah negara yang berdasarkan keTuhanan, sedang merawat kedua orang tua setelah masa renta adalah kewajiban yang diperintahkan Tuhan yang harus dilakukan oleh anak-anaknya karena kesuksesan anak-anak merupakan hasil perjuangan orang tua yang dilakukan dengan pantang menyerah, dan jauh dari rasa keluh kesah.

Keadaan lansia yang tetap sehat menjadikan anakanaknya merasa tenteram dalam perantauan, karena para lansia ini masih tetap mandiri, produktif, bahagia di usia senjanya. Keadaan tetap sehat memberikan dukungan untuk senantiasa giat beribadah sebagai bekal menghadap Sang Kuasa. Sehingga kebahagian dunia akhirat sebagai tujuan hidup orang beriman dapat tercapai.

\section{GEJALA PROSES PENUAAN}

Penuaan merupakan kejadian yang pasti dialami oleh setiap manusia. Dalam tubuh terjadi proses perubahan sruktur sel yang merupakan proses degeneneratif. Misalnya 
pembelahan sel melambat, sel mengecil, perubahan kompomsisi dan isi sel, serta timbulnya kemunduran fungsifungsi organ tubuh.

Gejala-gejala penuaan yang terjadi dalam tubuh diantaranya sebagai berikut: (1) kulit tubuh menipis, kering, tidak elastis, dan berkeriput, (2) rambut memutih, rontok, kering, dan tidak mengkilat. (3) jumlah serabut otot berkurang, ukurannya mengecil, volume ukuran otot secara keseluruhan menyusut, dan fungsinya menurun, (4) otot jantung mengalami perubahan degeneratif, ukuran Jantung mengecil, kekuatan memompa darah berkurang, pembuluh darah semakin kaku (arteriosklerosis), (6) terjadi degeneratif selaput lender dan bulu getar saluran pernafasan, gelembung Paru-paru menjadi kurang elastis, (7) tulang menjadi keropos (osteoporosis), (8) permukaan tulang rawan menjadi kasar hal ini sebagai akibat proses degeneratif, (9) penurunan fungsi ginjal sebagai alat penyaring darah, dan (10) penurunan fungsi fisiologis organ-organ tubuh lainnya (Hardianto Wibowo, 2003: 245).

Proses penuaan ini tidak dapat dihentikan, hal ini berjalan terus tanpa memandang ras, suku atau jenis kelamin. Misal adanya operasi plastik menjadikan kulit tetap kencang di usia senja, operasi sedot lemak tubuh menjadi

MEDIKORA Vol. IV, No 2, Oktober 2008: 146-167 
tetap langsing, penghitam rambut dan sebagainya, namun hal itu tidak akan dapat mempermuda fungsi kulit, jaringan lemak, dan rambut secara fisiologis tetapi itu hanya bersifat kamuflase.

Faktor usia/penuaan adalah gejala alam yang tidak dapat dihindari datangnya menimpa manusia. Penuaan mengakibatkan kemampuan baik fisik maupun psikis mengalami penurunan. Agar penurunan ini tidak berjalan terlalu cepat maka perlu adanya kiat-kiat khusus. Penurunan kondisi psikis yang parah adalah keadaan pikun di usia yang relatif belum terlalu tua misalnya usia 60-70 tahun. Sedang penurunan kondisi fisik yang parah adalah ketidakmampuan melakukan aktifitas untuk dirinya sendiri misalnya makan, buang air, mandi, ganti pakaian, berpindah dari tempat tidur akibat sakit karena penuaan yang dialami disaat usia belum terlalu tua. Hal ini terjadi akibat menurun dratis kualitas fungsi-fungsi organ tubuh.

Proses penuaan ini dapat diperlambat dengan tatap bekerja, makan makanan yang bergizi, berolah raga yang teratur dan terukur, perawatan tubuh yang baik, suana hati yang senang dan damai, serta aktif kegiatan sosial. Sebagai orang beriman aktif beribadah dengan banyak dikir, wirid, sholat sunah, membaca kitap suci dan amalan-amalan 
lainnya. Dari pengamatan diketahui bahwa orang yang aktif beribadah di usia lanjut lebih lambat pikun dibanding lansia yang tidak aktif beribadah. Hal ini mungkin disebabkan lansia yang aktif beribadah ini masih tetap mengaktifkan otak dengan cara selalu menginggat waktu datangnya sholat, menghafal doa doa, membaca kitap suci, melakukan amalanamalan sunah dan sebagainya.

\section{USAHA-USAHA MEMPERTAHANKAN KEBUGARAN DI USIA LANJUT}

Seseorang dikategorikan memasuki usia lanjut/lansia kira-kira usia 60 tahun atau lebih oleh karena itu sebagian besar peraturan kepegawaian menetapkan usia pensiun pada usia kurang lebih 60 tahun tersebut. Hal ini sesuai pengertian lansia pada UU Nomor 13 tahun 1998 tentang kesejahteraan lansia menyatakan bahwa lanjut usia adalah suatu proses yang tidak dapat dihindarkan yang berumur 60 tahun ke atas, pada usia itu kemampuan fisik atau psikis sedang mengalami penurunan. Cepat lambatnya penurunan kondisi fisik maupun psikis dipengaruhi oleh berbagai macam faktor diantaranya: tingkat pendidikan, ekonomi, kebiasaan perilaku hidup sehat, lingkungan sosial dan fisik, serta aktifitas fisik yang dilakukan.

MEDIKORA Vol. IV, No 2, Oktober 2008: 146-167 
Menurut Mansur (1996) dalam Sumintarsih (2006: 148) menyatakan bahwa kebugaran jasmani mempunyai hukum reversibility, pada prinsipnya manusia mempunyai adaptasi tinggi, baik terhadap stress latihan maupun Stress mental. Prinsip latihan yang harus diperhatikan adalah reversible atau berkebalikan, maksudnya adalah fungsi organ tubuh manusia mempunyai sifat alami, yaitu akan meningkat kemampuannya apabila diberi stress latihan dan berlaku sebaliknya jika dihentikan. Oleh karena itu usia lanjut secara alamiah mengalami penurunan kemampuan organ-organ tubuh agar laju penurunan (degradasi) tidak berlangsung cepat maka perlu senantiasa para lansia melakukan latihan agar kebugaran jasmani tetap terjaga.

Pengertian kebugaran adalah secara umum mengacu kepada kebugaran jasmani/fisik (psysical fitness), yakni kemampuan seseorang melakukan kerja sehari-hari secara efisien tanpa timbul kelelahan yang berlebihan. Menurut ahli fisiologi olahraga yang dikutip Mangi (1987) dalam Sumintarsih (2006: 148) menyatakan bahwa kebugaran jasmani adalah kapasitas seseorang untuk melakukan kerja dengan usaha yang minimal. Kebugaran jasmani dapat berarti kapasitas untuk dapat menyesuaikan diri terhadap latihan yang melelahkan dan segera pulih dari kelelahan 
tersebut. Amrum Bustaman dalam Harsuki (2003: 272) memberi pengertian tentang kesegaran jasmani adalah kemampuan tubuh seseorang untuk melakukan tugas kerja sehari-hari tanpa menimbulkan kelelahan yang berarti. Dengan demikian lansia yang mempunyai kesegaran jasmani yang baik adalah lansia yang masih dapat mengerjakan pekerjaan sehari-hari tanpa kelelahan yang berarti dan sedikit mengalami penderitaan sakit yang kronis. Menurut jenisnya lansia digolongkan menjadi dua: (1) lansia potensial, adalah lanjut usia yang masih masih mampu melakukan pekerjaan dan kegiatan yang dapat menghasilkan barang dan jasa, (2) lansia tidak potensial, adalah lansia yang tidak berdaya sehingga hidupnya bergantung pada orang lain.

Di negara yang berdasar keTuhanan baik lansia potensial maupun tidak potesial harus mendapat penghormatan yang memadahi, oleh karena para lansia telah banyak berjasa terhadap generasi penerus, masyarakat bangsa dan negara sampai tataran kemajuan jaman seperti sekarang ini. Kemajuan jaman dengan cepat arus informasi dan pesaingan di segala lini menjadikan paham materialisme menyusup dalam kehidupan manusia. Hal ini berdampak pada menurunnya rasa hormat kepada Lansia memudar dikarenakan adanya anggapan para lansia sudah tidak

MEDIKORA Vol. IV, No 2, Oktober 2008: 146-167 
produktif dan banyak ketergantungan pada orang lain. Menurunnya rasa hormat terhadap para lansia ini dapat dilihat dari gejala-gejala sebagai berikut: (1) Memudarnya sopan santun, hal ini seperti yang dikemukakan oleh Ketua Subbidang Peran Serta Masyarakat Lembaga Lanjut Usia Indonesia (LLI) Provinsi Jabar Sri Hartini. Di mata Sri yang merupakan perpanjangan lidah dari para lanjut usia (lansia), generasi muda sekarang terkesan tidak peduli kepada lansia. Kecenderungannya memang begitu. Ketika ada lansia yang hendak naik angkutan umum, anak-anak muda malah naik lebih dulu, para lansia tidak diberi kesempatan duduk. (2) Gambaran lain, kita sering menemui para lansia yang menggantungkan hidupnya di jalanan dengan cara mengemis. Berdasarkan data Dinas Sosial Provinsi Jabar, dari 3.371.521 lansia di Jabar, terdapat 236.721 lansia yang telantar (tak tertampung). Jumlah ini hampir sekitar 10 persen. Cukup memprihatinkan. (3) Banyak lansia hidup sendiri dengan kondisi tak berdaya padahal lansia tersebut mempunyai anak dan famili (google, lansia. htm. Suaramerdeka. Com)

Gejala sosial seperti tersebut di atas tidak boleh berlangsung terus, masyarakat harus bahu-membahu agar para lansia tetap mendapatkan kedudukan yang terhormat. Agama mengajarkan ridho ALLAH tergantung Ridho kedua 
orang tua. Surga terletak di telapak kaki ibu. Pembangunan tidak hanya ditujukan kepada pencapaian kemegahan fisik semata, tetapi lebih dari pada itu yakni untuk mencapai kesejahteran lahir, batin, dunia, dan akhirat.

Agar para lansia tetap terjaga tingkat kesegaran/kebugaran jasmaninya maka perlu aktif melakukan aktifitas fisik/olahraga agar tetap enerjik, produktif dan sedikit ketergantungannya pada orang lain, serta dapat menjalani ibadah dengan penuh semangat.

Ada beberapa komponen kebugaran jasmani diantaranya adalah: (1) kebugaran yang berhubungan dengan kesehatan yang terdiri dari: daya tahan kardovaskuler, kekuatan otot, daya tahan otot, fleksibilitas, komposisi tubuh, (2) kesegaran jasmani yang berhubungan dengan ketrampilan motorik yang terdiri dari: keseimbangan, daya ledak (power), kecepatan, kelincahan, koordinasi, dan kecepatan reaksi, (3) kesegaran jasmani yang berhubugan dengan kesejahteraan (wellness) dan kesehatan (health).

Untuk lansia potensial sangat penting manfaatnya untuk mempertahankan tingkat kebugaran jasmani sehingga para lansia tetap produktif, dan tingkat harapan hidup lebih panjang. Sedang untuk lansia tidak produktif latihan kebugaran bermanfaat memperlambat kecepatan penurunan

MEDIKORA Vol. IV, No 2, Oktober 2008: 146-167 
potensi organ tubuh sehingga tetap dapat melakukan aktifitas untuk kepentingan pribadi misalnya mandi, makan, buang air, ganti pakaian dan sebagainya.

\section{TIP-TIP MEMPERTAHANKAN KEBUGARAN LANSIA}

Tetap aktif latihan fisik/olahraga, bentuk latihan fisik yang dianjurkan untuk lansia diantaranya adalah: berjalan kaki, dengan berjalan kaki bermanfaat untuk meregangkan otot-otot, daya tahan, dan kelenturan. Menurut para ahli kesehatan melangkah 10.000 langkah tiap hari akan dapat menghambat pengeroposan tulang (osteoporosis), (2) bersepeda, olahraga ini baik untuk lansia yang menderita encok (artritis) karena berjalan kaki dapat menyebabkan nyeri pada sendi, juga bermanfaat meningkatkan peregangan, dan daya tahan, (3) Senam, olahraga ini dapat meningkatkan kelenturan, dan daya tahan Jantung dan pernafasan (cardiorespirasi), (4) Tenis dapat meningkatkan daya tahan tubuh, (5) Renang melatih seluruh anggota badan, dan peningkatan daya tahan peredaran darah dan pernafasan.

Berpola hidup sederhana, yakni bekerja setiap hari tetapi tidak memaksakan (memforsir) diri dilakukan dengan senang dan bahagia, menyempatkan diri bermain, sering mengirup udara segar, makan tiga kali sehari dengan ukuran sederhana, memelihara angan-angan yang bersih, 
menyelesaikan masalahnya dengan berdoa, dan tidur nyenyak seperti anak kecil.

Hindari gaya hidup selalu terburu-buru, jam, telepon dan alarm dapat menjadikan diri kita merasa terkejar-kejar waktu untuk segera menyelesaikan suatu urusan. Di saat beristirahat HP berdering/alarm berbunyi hal ini dapat menimbulkan ketegangan jiwa. Demikian juga kalender dapat menjadikan pikiran kita selalu menghitung-hitung waktu untuk menyelesaikan urusan, hal ini menjadikan pikiran terus bekerja bahkan sampai waktu tidur tiba, kadang dapat menjadikan sulit tidur. Agar dapat menghindari gaya hidup terburu-buru perlu dilakukan cara-cara sebagai berikut: (1) tidurlah lebih panjang, (2) bangunlah sejam lebih awal agar tidak tergesa-gesa, (3) makan pagi yang baik, (4) sekali waktu perlu menunda urusan sampai besok/sikap alpa, masa bodoh, lalai (nonchalant), tidak terlalu selalu serius atau bersungguh-sungguh, beristirahat, dan tertawa, dan (5) hadirkanlah ALLAH di hati disetiap waktu.

Menjaga kerja Jantung tetap landai, hal ini dapat dilakukan dengan: (1) jangan selalu tergesa-gesa, (2) jangan terlalu gemuk, (3) hindari keluh kesah, (4) jangan bekerja terlalu keras, (5) berhenti merokok, dan miras, (6) lakukan 
aktifitas fisik/olahraga ringan, dan (7) lakukan rekreasi/hiburan untuk mengendorkan syaraf.

Menolong perut dari menderita borok perut, para ahli kesehatan mengatakan bahwa perut adalah kaca pikiran. Pikiran yang dikacaukan oleh kesusahan dan kekacauan akan menekan rem fungsi-fungsi organ-organ tubuh. Pikiran cerewet, selalu marah-marah, mengirimkan dorongan kepada perut yang menimbulkan hamut tinggi, kejang, sakit ulu hati, dan rasa sakit yang menyebabkan malapetaka pada pencernaan. Bumbu-bumbu yang pedas kurang baik untuk penderita keluhan pencernaan, dan juga makanan yang banyak bumbu. Ahli kesehatan memperkirakan hampir 50\% pekerja perusahaan menderita penyakit: sembelit, borok perut hal oleh dokter disebut sebagai usus besar yang rewel atau sembelit bangkit. Penyakit ini tidak dapat diobati, obatnya adalah pikiran yang tenang, puas, dan bahagia. Ada beberapa hal yang dapat dilakukan untuk dapat menolong perut kita diantaranya: (1) tidur yang cukup 8-10 jam, (2) minum 2 gelas air putih sebelum makan pagi, dan 6-8 gelas sehari, (3) makan pagi yang baik dan cukup, (4) jangan bekerja memaksakan diri, (5) bekerja selesai lebih awal agar jangan selalu tergesa-gesa, (6) melakukan aktifitas fisik, (7) jangan minum obat sembarangan tanpa resep dokter, (8) 
hindari perasaan selalu dikejar-kejar waktu, dan selalu tegang, dan (9) lalui hidup dengan rasa senang.

Melakukan sesuatu menjadi hobi (kegemaran) yang sehat, pemenuhan terhadap hobi/kegemaran akan menimbulkan kebahagian dan ketentraman misalnya memelihara burung, berkebun bunga, berternak ayam pelung, mengumpulkan prangko, mengkliping berita menarik, koleksi barang-barang antik, memancing, main layanglayang, dan sebagainya. Namun sebagai lansia penyaluran hobi ini jangan sampai menimbulkan kelelahan yang berlebihan, jika demikian maka hobi akan mempunyai akibat sebaliknya. Melihat-lihat air adalah resep kuno yang baik untuk penderita tekanan darah tinggi, pergerakan air mengendurkan syaraf, ketegangan otot, dan tekanan Jantung.

Sering menghirup udara yang bersih, kemajuan teknologi dengan semakin banyaknya kendaraan bermotor yang selalu mengeluarkan gas karbon monoksida menjadikan kualitas udara mengalami penurunan. Bangun lebih pagi sekedar berjalan-jalan pagi di alam pedesaan/taman-taman banyak pohon rindang mampu meningkatkan kebugaran tubuh.

MEDIKORA Vol. IV, No 2, Oktober 2008: 146-167 
Berjemur di sinar Matahari pagi, hal ini akan meningkatkan kelancaran peredaran darah, dan sinar matahari pagi ini dapat berguna untuk memproses pro vitamin D menjadi vitamin D yang sangat dibutuhkan untuk kesehatan.

Gunakan kursi goyang, dahulu orang-orang kaya banyak menggunakan kursi goyang ini untuk bersantai, namun dengan semakin banyak jumlah penduduk dan menyempitnya lahan pemukiman orang cenderung memilih bentuk rumah yang kecil dan praktis dengan alasan tidak terlalu menyita waktu dan tenaga saat membersihkan. Alasan ini berdampak buruk terhadap nasip kursi goyang karena dianggap menyita tempat dan tidak diperlukan maka disingkirkan atau dimusnahkan. Kursi goyang ini padahal besar manfaatnya untuk mengedurkan syaraf, dan ketegangan jiwa. Oom Tom Saxe orang Amerika kepala restoran White Tower dan pendiri perkumpulan duduk, ketika di Florida duduk di sebuah kursi goyang di sebuah hotel tuan Saxe mendapat pikiran yang baik, mengapa tidak diajak orang duduk pada kursi goyang dan mengendurkan ketegangan beberapa menit lamanya tiap hari? Usaha demikian akan menghindarkan borok atau tukak perut dan penyakit syaraf. 
Oom Tom benar adanya, jika berkata bahwa akan berkurang orang yang berpenyakit syaraf dan tukak perut. Perbuatan menggoyang-goyang kursi goyang dengan senangnya condong kepada ketenangan pikiran, hal ini hampir sama dengan perjalanan mempergunakan kapal, itu perjalanan kapal di rumah sendiri. Kapal yang goyang itu menantang pemusatan pikiran buat waktu yang cukup lama. Duduk dengan bergoyang di kursi goyang sama akibatnya ditenangkan pikiran, hilang keluh kesah, meredakan ketegangan otot, dan mendapatkan ketenangan jiwa.

Mengendurkan syaraf, kehidupan modern penuh kompetisi banyak menimbulkan ketegangan jiwa. Hal ini dapat mengakibatkan ganguan syaraf, tukak perut, tekanan darah tinggi, penyakit jantung, dan stroke. Kehidupan dengan ala pedesaan yakni makanan yang alami dan cukup, rumah besar dan berudara segar, pekarangan yang hijau dan sejuk, pohon-pohon yang tinggi dan rindang, gudang padi, kebun, sawah, ladang dan hutan, burung berkicau, suara kemericik air, dan sebagainya dapat meredakan ketegangan syaraf.

Menghindari keluh-kesah, keluh kesah adalah pikiran yang berputar-putar tidak ada ujung pakalnya dan tidak ada panyelesainya. Keluh kesah berarti memandang ke depan dan ke belakang tetapi tidak berbuat apa-apa untuk

MEDIKORA Vol. IV, No 2, Oktober 2008: 146-167 
menyelesaikan apa yang dipikirkannya. Ada beberapa cara untuk menghilangkan keluh kesah diantaranya: (1) kalahkan keluh kesah dengan berbuat sesuatu, lebih baik berbuat dan salah dari pada hanya berfikir saja tanpa berbuat sesuatu. (2) curahkan isi hati pada orang lain yang terpercaya, dan (3) bertawakal kepada Allah.

Menghindari stress, karena dapat memicu munculnya berbagai macam penyakit. Data di Amerika menunjukkan bahwa 16 juta orang Amerika mengalami depresi, dan kirakira 32 juta orang mmengalami ketegangan jiwa (anxiety) dan reaksi stress. Ketegangan jiwa (anxiety) merupakan masalah nomer satu tentang kesehatan mental yang diderita masyarakat Amerika usia 18 sampai 54 tahun. Ini kira-kira $13 \%$ dari jumlah penduduk yang berusia dewasa muda. Lebih dari 13 juta usia muda 9 sampai 17 tahun mengalami kecemasan. Munculnya kecemasan dan stres ini dapat dipicu oleh keadaan di masyarakat misalnya: pengangguran, kebisingan, inflasi, persaingan, rasisme, problem seksualitas, krisis keuangan, kejahatan, perjudian, minuman keras, dan sebagainya. Masalah kesehatan mental mencapai lebih dari $30 \%$ total penderita sakit di rumah sakit di Amerika setiap harinya, dan mencapai 10\% total biaya kesehatan (Robert S. Weinberg, Daniel Gould, 2003: 384). 
Makan makanan yang sehat dan alami, terutama buah dan sayur-mayur segar, alami, dan organik. Sedapat mungkin mengurangi makanan dan minuman mengandung kolesterol tinggi, sulit dicerna, makanan siap saji dengan bahan pengawet, minuman beralkohol dan berkadar gula tinggi. Makanan yang mengandung banyak serat baik untuk dikonsunsi karena makanan ini dapat menyerap kelesterol darah dan memperlambat rasa lapar, hal ini dapat dipergunakan untuk mengontrol berat badan (James Anderson, 1996: 368).

Hindari ketergantungan pada obat, pada tahal awal obat dapat membantu menyembuhkan penyakit namun apabila obat ini dikomsumsi secara terus menerus justru berdampak sebaliknya yakni menjadi racun dalam tubuh dan kuman menjadi kebal terhadap obat tersebut, terutama untuk obatobat anti biotik. Berusahalah agar tubuh dapat menghalau penyakit dengan kemampuannya sendiri dengan cara makan makanan yang bergizi dalam jumlah yang cukup, istirahat yang cukup, dan melakukan aktifitas jasmani.

Tetaplah aktif membaca dan menulis, karena aktif membaca dan menulis seperti mengolahragakan otak sehingga otak senantiasa aktif. Otak yang aktif akan dapat memperlambat proses kepikunan. Bacaan yang baik untuk

MEDIKORA Vol. IV, No 2, Oktober 2008: 146-167 
lansia diantaranya: buku agama, bacaan-bacaan ringan misalnya kisah, berita koran atau majalah, buku cerita, buku budaya, dan sebagainya.

Melakukan rekreasi yang ringan dan murah, sekedar berjalan-jalan melihat pesawahan yang menghijau, melihatlihat aliran sungai atau irigasi sawah, melihat kolam ikan, ternak di penggembalaan, burung-burung berterbangan dan berkicau di alam bebas sudalah cukup untuk menyenangkan hati dan menimbulkan semangat baru.

Semakin giat menjalankan ibadah, keyakinan akan adanya alam Baka, kehidupan sesudah mati para lansia harus berusaha mendapatkan kebahagian di alam sana. Kematian pasti terjadi, kematian adalah pintu memasuki alam baka. Kejayaan di dunia tidak dapat menjadi jaminan kebahagiaan di alam baka, hanya keimanan, pengabdian, dan ketaatan kepada Sang Pencipta yang dapat menjadi modal hidup di alam baka. Secara normal lansia lebih dekat dengan kematian dibanding remaja oleh karena itu maka preoritas aktifitas hendaknya dipergunakan untuk mengejar kejayaan di alam baka. Berkompetisi memperebutkan kejayaan dunia mulai semakin di kendurkan karena puncak prestasinya di dunia apapun wujudnya telah tercapai dan mulai berpacu memperebutkan tempat kejayaan di alam baka. Kebahagiaan 
hidup manusia yang sebenarnya tidak hanya didunia ini tetapi juga kebahagiaan di alam baka.

\section{DAFTAR PUSTAKA}

Harsuki. (2003). Perkembangan Olahraga Terkini Kajian Para Pakar. Jakarta: PT Rajagrafindo Persada.

Hardiyanto Wibowo. (2003). Lanjut Usia dan Olahraga. Jakarta: PT Grafindo Persada.

J. Dewitt Fox. (1995). Nasihat Dokter. Bandung: Indonesia Publishing House P.O. Box 95.

Matthew hoffman, William LeGro. (1996). Bebas dari Penyakit Mencegah, Mengobati, dan Menyembuhkan Lebih Dari 100 Penyakit dan Idapan. Jakarta: PT gramedia Pustaka Utama.

Robert S. Weinberg, Daniel Gould. (2003). Foundations Of Sport and Exercise Psychology Third Edition. USA: Human Kinetik, P.O. Box 5076, champaign, IL 618255076.

Sumintarsih. (volume 12, agustus 2006). Majalah Imiah Olahraga Fakultas Ilmu Keolahragaan-Universitas Negeri Yogyakarta. Yogyakarta: FIK.

WWW. Google. Lansia.htm, Suaramerdeka. com. Menjaga dan Merawat Lansia. Diambil tanggal 16 Desember 2008.

MEDIKORA Vol. IV, No 2, Oktober 2008: 146-167 